\title{
The Drought of the Century in the Amazon Basin: An Analysis of the Regional Variation of Rainfall in South America in 1926.
}

\author{
Earle WILLIAMS ${ }^{1}$; Alaor DALL' ANTONIA; Vitoria DALL' ANTONIA; Jorge Mathias de ALMEIDA and \\ Francisco SUAREZ ${ }^{2}$; Brant LIEBMANN ${ }^{3}$; Ana Claudia Mendes MALHADO ${ }^{4}$
}

\begin{abstract}
The most severe drought in tropical South America during the $20^{\text {th }}$ century occurred in 1926. This extreme El Nino year is further documented anecdotally, in an update of the river stage observations at Manaus, and in annual rainfall records. The annual rainfall anomaly is an east-west dipole over tropical South America, with drought to the west over the Amazon basin whose discharge is documented at Manaus, and with a surplus to the east and including the Nordeste region of Brazil. Speculations about a role for aerosol in aggravating the drought are discussed.
\end{abstract}

KEY-WORDS

Rainfall, climatic history, drought

\section{A seca do século na Bacia Amazônica: Uma análise da variação regional de chuva na América do Sul em 1926.}

RESUMO

A mais severa seca nos trópicos da América do Sul durante o século 20 ocorreu em 1926. Este ano extremo de El Niño é documentado nos níveis de observações do rio (Negro) em Manaus, nos registros anuais de precipitação e anedoticamente. A anomalia anual de precipitação é um dipolo leste-oeste sobre os trópicos da América do Sul, com seca a oeste sobre a bacia Amazônica cuja a descarga é documentada em Manaus, e um residuo para o leste incluindo a região nordeste do Brasil. Especulações sobre a função dos aerosóis na agravação da seca são discutidos.

\section{PALAVRASCHAVE}

chuva, história climática, seca

\section{INTRODUCTION}

The zonal variation of land surface area in the tropics gives rise to three prominent 'chimney' regions of convective upwelling - South America, Africa and the Maritime Continent. The tropical population of thunderstorms is largely contained within the chimneys (Orville and Henderson, 1986; Christian et al, 2003) which in turn are well recognized components of the global electrical circuit (Whipple, 1929). The chimneys are also dominant centers of latent heat release and conduits for the transport of water substance to the upper troposphere (Kent et al, 1995), thereby emphasizing their importance for global climate. Two of the chimneys-South America and Africa, are drained by major rivers - the Amazon and the Congo, respectively, which serve as giant natural raingauges for chimney rainfall (Riehl and Meitin, 1979; Richey et al, 1989; Marengo, 1995; Amarasekera et al, 1997). The zonal variation of land surface area also underlies the tropical Walker circulation. Variations in

\footnotetext{
${ }^{1}$ Parsons Laboratory, Massachusetts Institute of Technology, Cambridge, MA USA

${ }^{2}$ Instituto Nacional de Meteorologia (INMET), Brasilia, Brazil

${ }^{3}$ NOAA CIRES Climate Diagnostics Center, Boulder, CO 80307, USA

${ }^{4}$ School of Geography and Environment, University of Oxford, Oxford, England
} 


\section{ACTA \\ AMAZONICA}

THE DROUGHT OF THE CENTURY IN THE AMAZON BASIN:

AN ANALYSIS OF THE REGIONAL VARIATION OF RAINFALL IN SOUTH AMERICA IN 1926. the Walker circulation on the ENSO time scale are recognized to cause systematic variations in chimney rainfall (Richey et al, 1989; Amerasekera et al, 1997).

In a landmark paper, Richey et al (1989) investigated the short-period climate implications in the $20^{\text {th }}$ century record of discharge from that portion of the Amazon basin upstream from Manaus, Amazonas, Brazil. This record is reproduced in Figure 1. The location of the Manaus gauge, the boundaries of the upper Amazon basin it measures, and the total Amazon basin (drained mainly at Macapá on the Atlantic Ocean), are shown in Figure 2. The present study is concerned with the most pronounced anomaly in this record, noted initially in the raw river stage observations by Sternberg (1987), the minimum in discharge in 1926 . This year is widely recognized as an El Nino year (Allen et al, 1996; Xavier, 2001). The magnitude of the anomaly is remarkable in showing a 50\% reduction from the climatological mean in total discharge of the largest river basin in the world, and by inference a major perturbation in heat balance of one of three tropical continental chimneys.

This study is concerned with an examination of historical rainfall records over tropical South America during the 1920s toward verifying the driest year there in the $20^{\text {th }}$ century. This work is also aimed at understanding the regional variation of the rainfall anomaly on a scale larger than the drainage area contributing to the river flow at Manaus, Brazil.

\section{THE EXTENDED RECORD OF RIVER STAGE AT MANAUS}

The period of river gauging in the Rio Negro at Manaus has recently exceeded 100 years. Figure 3 shows the century-long (1903-2003) records of annual maximum and minimum stage, in meters above local datum, to update the earlier analyses by Richey et al (1989) and Obregon and Nobre (2002) for the $20^{\text {th }}$ century. The mean high water is 27.8 meters. The high water mark in 1926 was 6 meters less at 21.8 meters, more than five standard deviations below the mean. The 1926 year is by far the

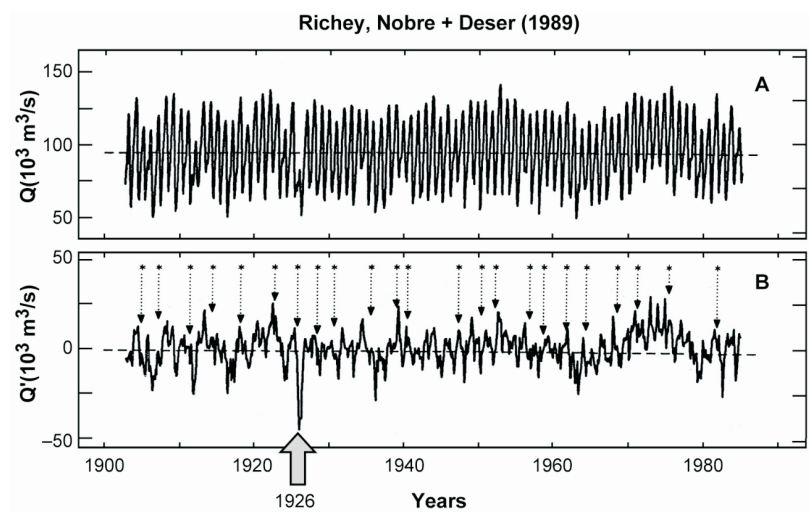

Figure 1 - Discharge records for the Amazon (1903-1985) at Manacapuru (near Manaus) (a) discharge time series and (b) deseasonalized discharge, based on Richey et al (1989). most anomalous in this record. A minimum low water value was also documented in 1997, the most recent El Nino year. Local minima in both the low water and the high water marks are noted in 1983, another El Nino year.

\section{BACKGROUND DOCUMENTATION OF THE DRY YEARS}

The first author's initial exposure to the anomalous year 1926 in the Amazon basin came through discussions in the early 1980s from the late John Edmond at MIT, who had devoted considerable attention to the geochemistry of river water in this basin (e.g., Stallard and Edmond, 1981). Edmond's specific knowledge about the anomaly had in turn originated from Robert Meade, a colleague at the U.S. Geological Survey who had developed considerable expertise in the streams of the Amazon basin (e.g., Meade et al, 1985; 1991), in part through an effort to recover existing stage records throughout South America. But Meade's knowledge and interest in the 1926 anomaly had developed even earlier from a book that shaped his entire career as a hydrologist. As a teenager living in Venezuela, Meade had read an adventure story (Caroni Gold by Dennison, 1943) about an American who traveled to Venezuela for a mining company in the 1920 s in search of gold. (The Caroni River is a tributary of the Orinoco in Venezuela.) Numerous quotations from Dennison (1943) pertain to the 1926 anomaly and a previous dry year (1912) in that part of South America.

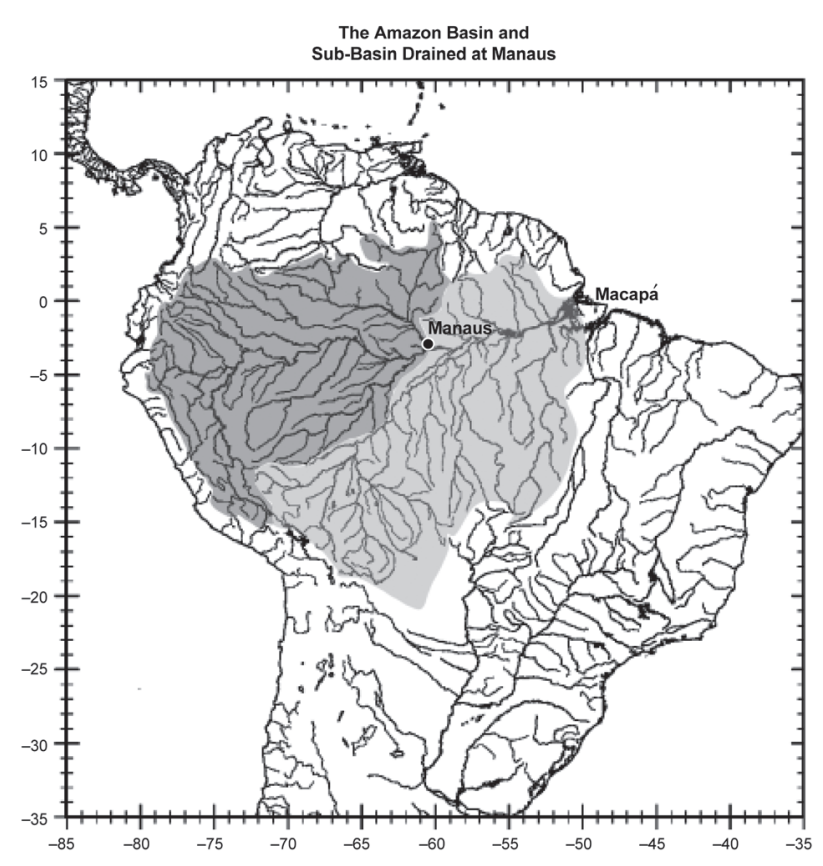

Figure 2 - Major streams in South America with the Amazon basin outlined and with the Amazon sub-basin drained near Manaus darkened. 


\section{ACTA AMAZONICA}

THE DROUGHT OF THE CENTURY IN THE AMAZON BASIN:

AN ANALYSIS OF THE REGIONAL VARIATION OF RAINFALL IN SOUTH AMERICA IN 1926.

"Do you really think that the Caroni (River) will go down as low as it did in 1912?", I asked, to see if he had any good argument to offer.

"Well, señor, one can never tell, but the seasons seem to run in cycles in this country. Fourteen years have now elapsed since the river went down low and the Indians say that it will go down this year. If it does as the Indians say, you will be a very lucky man, for you will see a sight that very few engineers will ever see." (p. 169).

The evidence for the dry year in 1912 is also apparent in the Amazon discharge record in Figure 1, as the minimum discharge prior to 1926 . Koch-Grunberg $(1917$, p.226) and Knoch (1926) have also written about the unusually dry summer in 1912 in the vicinity of the border between Venezuela and Brazil, an area impacting the discharge at Manaus (see Figures 1 and 3). Global maps of sea surface temperature (Allan et al, 1996) show elevated temperature surrounding South America for that year-evidence for an El Nino year.

Of the dry year 1926, the main focus for the present study, Dennison (1943) wrote:

"The dry season of 1926 again gave the opportunity for which they had waited fourteen years. That season was the driest ever known in Venezuela and thousands of beautiful diamonds, together with many ounces of gold, were recovered by the primitive use of bateas - native wooden mining pans. The river did not rise until the end of May. Then when the belated rains started in the back country the Caroni River, like a jealous mother, bid her treasures beneath an immense blanket of water.

Each year the natives anxiously watch for the river to recede once more, gathering upon its banks during the dry season and patiently waiting. The Caroni must be angry, they say, for another fourteen years has now passed and the rich treasures bave not again been exposed." (p. xii)

And further:

"As there had been no rain for some time, an almost unbeard of condition in Venezuela, the people bung their hammocks

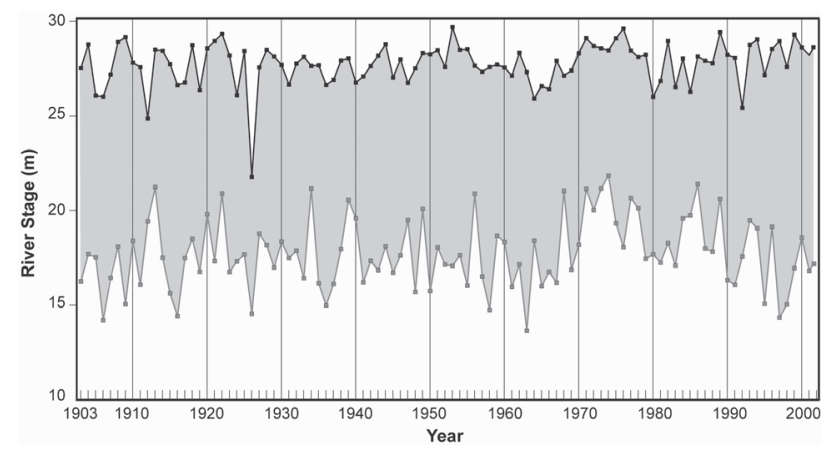

Figure 3 - Century-long records of annual maximum (top) and annual minimum (bottom) river stage (in meters) at Manaus, Amazonas, Brazil on the Rio Negro. The most pronounced anomaly in the record, the reduced maximum stage in 1926, stands out clearly. (Recent analysis of Moody and Meade (1998) suggests that mean sea level stands at +4.42 meters on this vertical scale.) under the trees without bothering to build any protection. Jungle fires were common and the country experienced the driest season on record." (p. 241).

Several previous studies and reports (Knoch, 1926; Knoche, 1937; Carvalho, 1952; and Sternberg (1968; 1987)) discuss the anomalous dry year 1926, and the extensive fires and "grossa humareda" ("big smoke") that prevailed in Venezuela and the Rio Negro basin of the upper Amazon. Knoche (1937) documents the surface temperature anomaly in three Venezuelan cities for both 1925 and 1926. More recent studies of sea surface temperature (Allan et al, 1996) show the most enhanced anomaly in the $20^{\text {th }}$ century surrounding South America, consistent with a pronounced El Nino period for both 1925 and particularly 1926. Knoche (1937) also notes that annual rainfall totals are less in 1925 than 1926 in three Venezuelan cities.

\section{COLLECTION AND ANALYSIS OF SOUTH AMERICAN RAINFALL DATA}

The major task in this study was the identification of archives for monthly rainfall for the decade 1920-1930 at any station within tropical South America. In light of evidence for the dry year in 1925 in Venezuela, stations were also sought within the Orinoco River basin adjacent to the Amazon to the north (Figure 2), and containing the Caroni River as a tributary.

The most important contributing archive for this study was the Instituto Nacional de Meteorologia (INMET) in Brasilia, where the great majority of Brazilian historical meteorological observations are stored, in their original data books. The search for station data in the Brazilian states of Acre, Amazonas, Rondônia, Mato Grosso, Para and Maranhao is believed to be exhaustive for the chosen decade, and many stations there had been operational for only a few years prior to 1926. Annual rainfall variations at 32 stations in northwest Brasil (from the states of Ceara, Rio Grande do Norte, Paraiba, Pernambuco, Alagoas, Sergipe, Bahia and Minas Gerais) were taken from an earlier study by Kousky and Chu (1978). Additional stations in southern Brazil may come to light in the data digitization effort currently underway in Brasilia, and may provide further information on the overall rainfall anomaly in future studies.

Additional rainfall data were obtained from the Venezuelan Ministry of the Environment for about thirty stations. A few additional stations were provided for Peru, Ecuador, and Colombia by INPE in Cachoeira Paulista, Brazil.

Given the spotty nature of the available rainfall data in the 1920 's, and the substantial variance of the monthly estimates at any given station, it was decided to work with rainfall anomalies on the annual time scale. This strategy is also appropriate for an ENSO phenomenon with a time scale significantly longer than one year. The annual rainfall anomalies were computed against the mean annual rainfall, where the means were computed on the basis of the longest station record available. All annual rainfall anomalies are expressed as a percentage departure from the mean annual value. 


\section{ACTA \\ AMAZONICA}

THE DROUGHT OF THE CENTURY IN THE AMAZON BASIN:

AN ANALYSIS OF THE REGIONAL VARIATION OF RAINFALL IN SOUTH AMERICA IN 1926.

\section{RESULTS}

The annual rainfall anomalies for ten selected Venezuelan stations for the period 1920-1930 are shown in Figure 4. Eight of these ten stations show the largest negative anomaly in 1925 rather than 1926, in agreement with the 3-station comparison found in Knoche (1937). Three of these annual anomalies are in the $40-70 \%$ range and hence are quite substantial. Two stations however show the strongest negative anomalies in 1926 rather than in 1925. In general, however, the evidence in Figure 4 is consistent with the idea that a dryer-than-normal year in 1925 helped set the stage for the 1926 drought.

Figure 5 summarizes the annual rainfall anomalies for the low-discharge year 1926 for all stations for which data are available in this study over South America. In general, the station climatology was based on the decadal period 1920-1930. Also shown again are the sub-basins of the Amazon noted earlier in Figure 2. In general, negative rainfall anomalies are found in the sub-basin contributing discharge of the Amazon near Manaus (with a single exception), and positive anomalies are found further to the east, and including the Nordeste region (Kousky and Chu, 1978; Hastenrath et al, 1984). The overall rainfall anomaly is therefore a dipole with approximate east-west extent.

Rainfall anomaly records for three selected individual stations are shown in Figure 6. In all cases, a pronounced negative anomaly is evident in 1926, consistent with the independent evidence for major drought, widespread fire, and smoke.

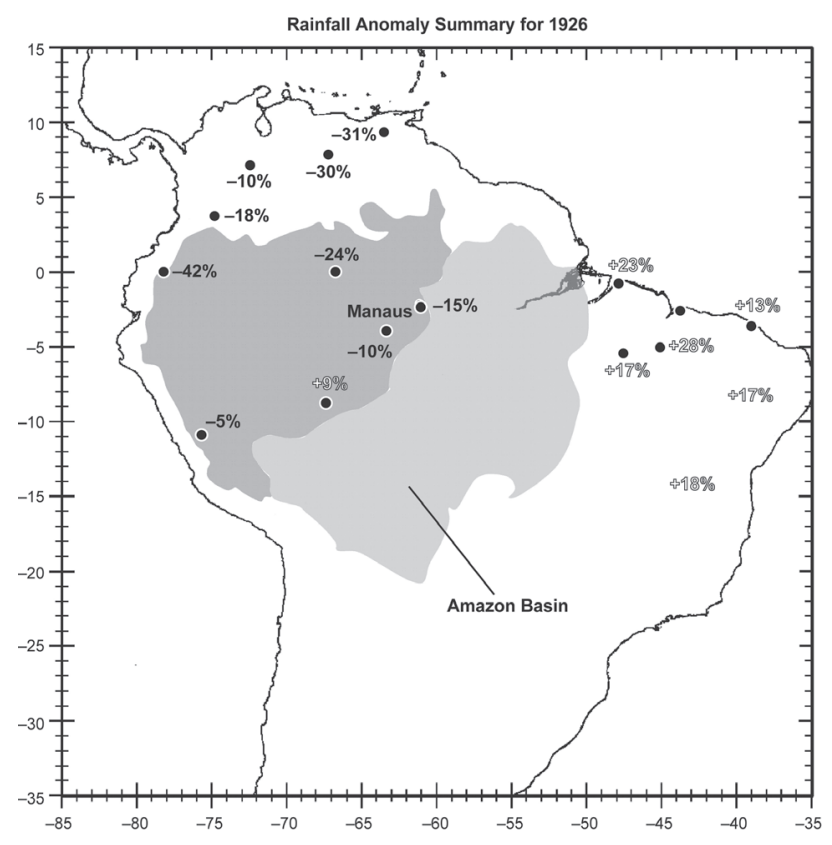

Figure 5 - Summary of the annual (January-December) rainfall anomaly for the dry year of 1926 over South America for all stations available in this study. An east-west dipole is apparent, with reduced rainfall upstream from Manaus and enhanced rainfall further east and extending to the Nordeste region.

\section{DISCUSSION}

The rainfall data for Venezuela for 1925 were investigated because of earlier suggestions for dryer-than-normal conditions in that year as well (Knoche, 1937). This evidence has been confirmed. The negative anomaly in rainfall in Venezuela documented at multiple stations in Figure 4 may have partial explanation in the low sea surface temperature on the northern boundary of South America, beginning in 1924 (a La Nina year) and sustained throughout 1925 (Allan et al, 1996). It is plausible that the dryness in the northern portion of the Rio Negro basin in 1925 also contributed to the major drought in 1926, by both a depletion of soil moisture and possibly a negative feedback on rainfall from abundant smoke aerosol (see below for elaboration). The 1925 event evidently had smaller regional extent because no negative anomaly is evident in either the discharge (Figure 1) or the stage (Figure 3) records.

Though the station observations are spotty even on the scale of the upper Amazon sub-basin (with only 6 stations within the upper basin), the annual rainfall deficits are broadly consistent with the deficit in annual discharge for 1926, estimated from Figure 1 to be 30-40\%. The deficit in peak discharge during 1926 is closer to $50 \%$.

The year 1926 is without ambiguity a pronounced El Nino ("warm") year. Examination of the historical record on the Southern Oscillation Index (1876-2003) (http:// www.bom.gov.au/climate/current/soihtm1.shtml) shows a sustained negative index for 16 months associated with the 1926 dry year, beginning in May of 1925 . (In contrast the maximum negative amplitude of the SOI for this El Nino period $(-14.5)$ is unremarkable against many other El Nino episodes in the record.) In the 129 years of this SOI record, a sustained period of negative monthly values greater than 16 months occurs only three times, and one of them is the 1911-1912 period that is also a conspicuous drought in the Amazon records in Figures 1 and 3, and subject of discussion in Dennison (1943). The characteristic positive SST anomaly in the eastern Pacific Ocean is strengthening throughout 1925 (Murphy, 1926) and maximizes in April of 1926, when low surface pressure also prevails in the eastern Pacific and high pressure in the Maritime Continent (Allan et al, 1996). The major upwelling in the central and eastern Pacific and compensating enhanced subsidence over the tropical continental chimneys (Figure 7) provides a simple scenario for the tendency for reduced rainfall and river discharge over tropical South America in the warm phase of the ENSO (Richey et al, 1989; Xie et al, 1996; Amerasekera et al, 1997). The subsidence and reduction in cloudiness enhances the solar radiation reaching the surface, the most plausible explanation for the elevated surface temperatures in that year 1926 noted by Knoche (1937), and documented as a general feature of tropical continental chimneys in the warm phase (Hansen and Lebedeff, 1987; Williams, 1992). Knoche (1937) had suggested a contribution to elevated temperature from forest fire, but the fires are generally highly localized and the elevated temperatures in the warm phase of the ENSO are know to occur in the absence of fire. 

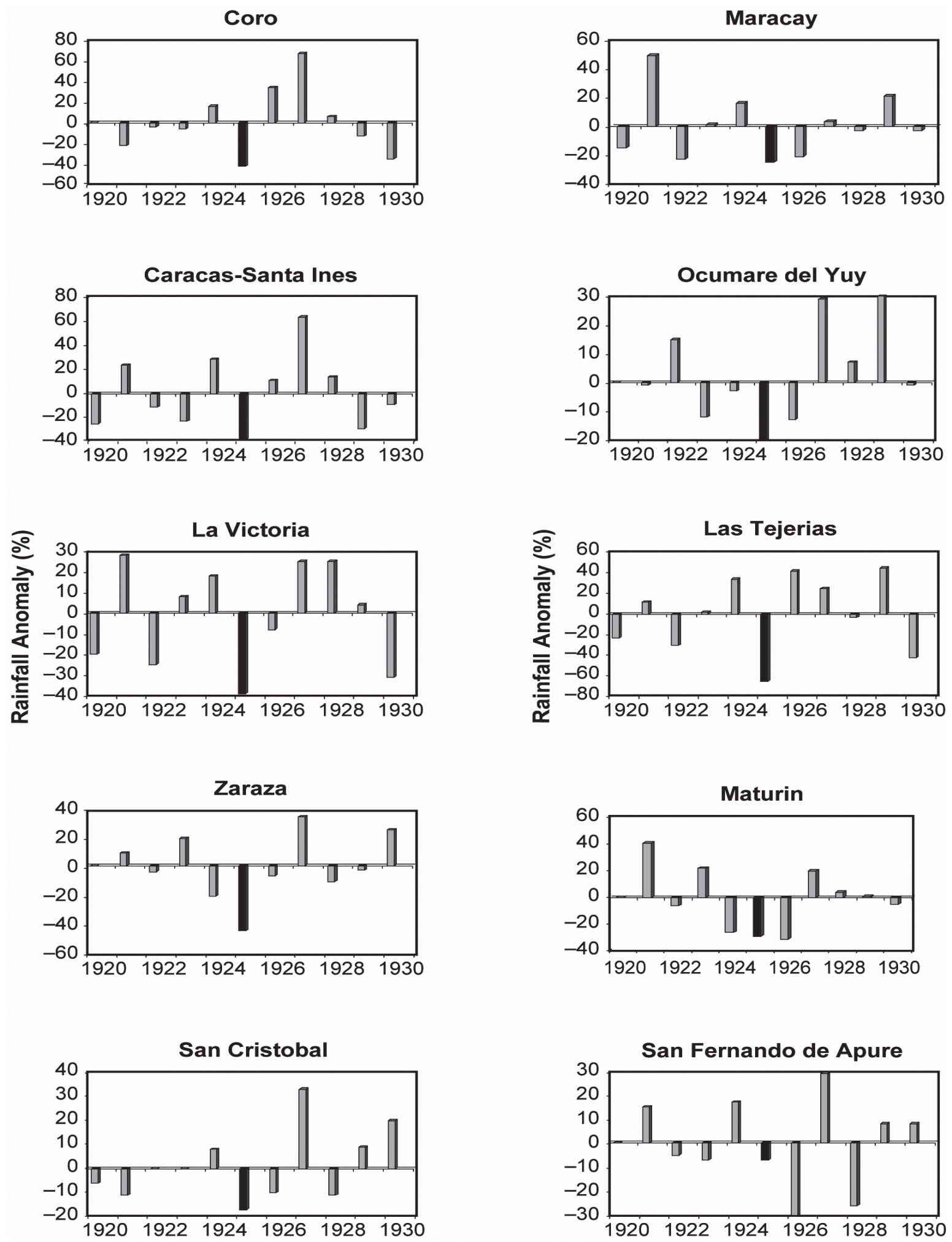

Figure 4 - Annual rainfall anomaly at ten selected stations in Venezuela for the decade 1920-1930. The anomaly is computed as the percentage departure from the mean computed over this decade. (Data courtesy of the Venezuelan Ministry of the Environment). 


\section{ACTA AMAZONICA}

THE DROUGHT OF THE CENTURY IN THE AMAZON BASIN:

AN ANALYSIS OF THE REGIONAL VARIATION OF RAINFALL IN SOUTH AMERICA IN 1926.
Despite the broad consistency between the behavior in 1926 and in other El Nino years, two puzzles remain. Why the non-canonical distribution of rainfall indicated in Figure 5, and why the pronounced departure from the mean (five standard deviations in the maximum river stage) in Figure 3? These issues are discussed in turn.

The annual rainfall anomaly map in Figure 5 departs significantly from the canonical El Nino year (Ropelewski and Halpert, 1987; Kiladis and Diaz, 1989) in showing enhanced rainfall over the Nordeste region of Brazil. There is little question
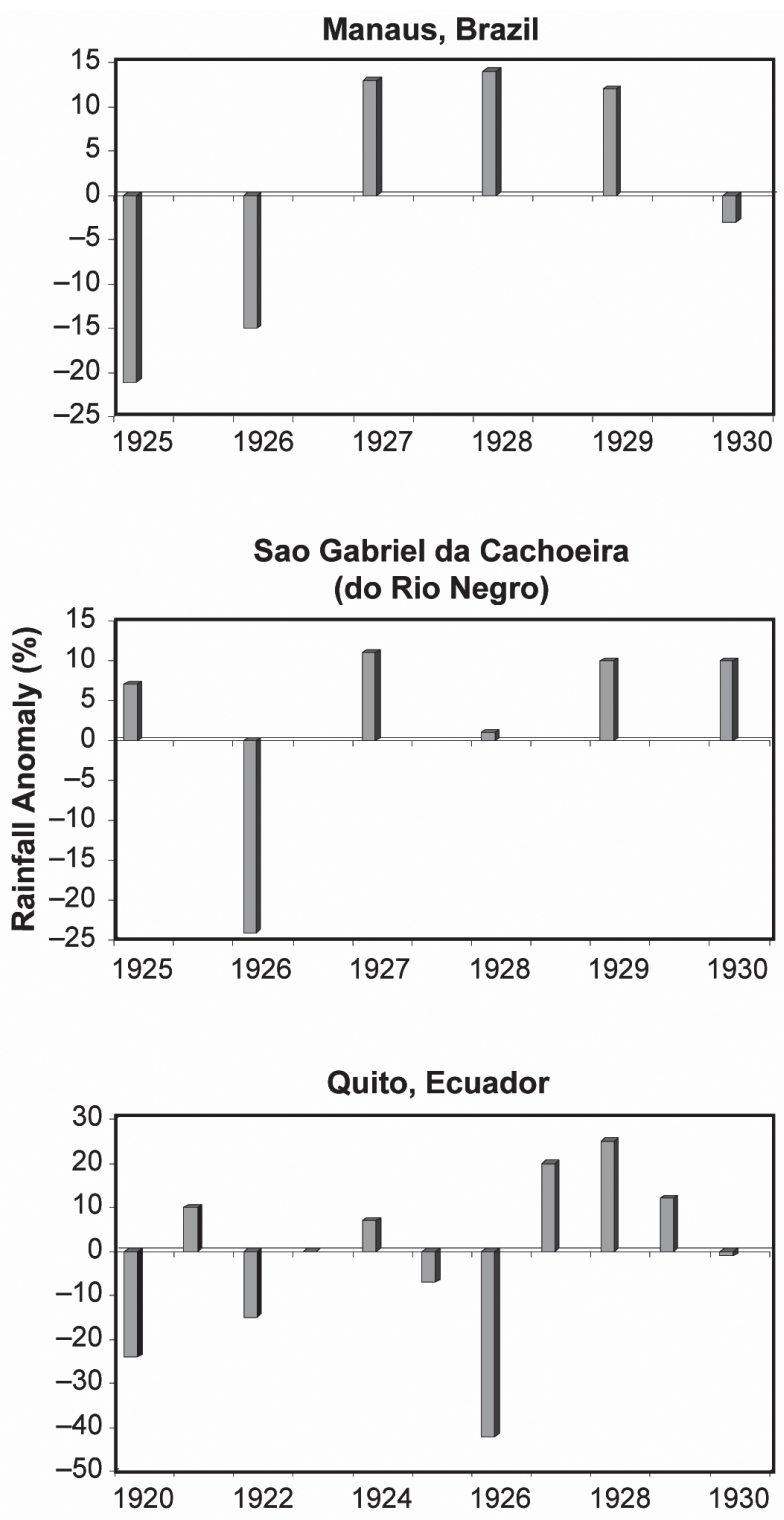

Figure 6 - Annual rainfall anomaly at three stations upstream (west) of Manaus, showing pronounced negative anomalies in the dry year 1926. about enhanced rainfall in the Nordeste in 1926.32 of 36 stations examined by Kousky and Chu (1978) showed positive annual rainfall anomalies in 1926. Later analysis by Hastenrath et al (1984) is consistent for 1926. According to Xavier (2001), for 135 raingauges in Ceara in the year 1926, 22\% were in the category VERY RAINY, 26\% were in the category RAINY, 33\% were in the category NORMAL, and only $16 \%$ in the categories DRY and VERY DRY. Ordinarily, severe drought manifests itself in this region in El Nino years, in addition to dryness in the Amazon basin further west (Markham and McLain, 1977; Hastenrath et al, 1984; Ropelewski and Halpert, 1987; Marengo, 1992). The droughts of the Nordeste are also associated with lower-than-normal SST in the South Atlantic Ocean. Though this condition is common during many El Nino events, such a condition did not exist during the El Nino of 1926. SST maps in Allan et al (1996) show elevated SST in the South Atlantic beginning in late 1925, and persisting through 1926 into early 1927. This feature is included in the illustration in Figure 7 as an enhancement in upwelling and attendant rainfall over the Nordeste region in 1926. Regarding the situation in southeastern South America, the 1926 El Nino year is more canonical (Ropelewski and Halpert, 1987; Ferreira et al, 2002), with evidence for enhanced streamflow in the Parana River (in southern Brazil) during 1926 (Amerasekera et al, 1997).

The second puzzle in this study, less easily resolved, is the extreme magnitude of the negative anomaly in river records in 1926. As previously noted, this El Nino event was meteorologically extreme in its duration, but the apparent change in the water balance is really extreme. Given the presence of fire and abundant smoke in 1926 (Knoch, 1926; Knoche, 1937), one can speculate about the possible negative feedback effect on the rainfall with abundant aerosol (Rosenfeld, 1999; Williams et al, 2002). The aerosol may serve to reduce the size of cloud droplets and thereby suppress further the process of warm rain coalescence that is ordinarily the predominant mechanism for tropical rainfall. The impact of aerosol is likely to be greatest in a drought phase because the abundant convection and rainfall is absent that efficiently removes the aerosol from the troposphere. Model calculations are needed to quantify the speculation on the negative rainfall feedback.

As a final note, it is important to emphasize the regional nature of the rainfall anomaly within the South American chimney documented in Figure 5. Despite an extraordinary negative rainfall anomaly in the western Amazon basin (consistent with the negative anomaly in the river records in that year), and an extraordinary positive anomaly further east, the overall anomaly for South America for 1926 is greatly diluted, and is in fact aliased by the river record. This removes the concern about the major adjustment in heat balance for the South American chimney, and further emphasizes the need to consider regional effects in understanding ENSO anomalies.

\section{CONCLUSIONS}

The 1926 drought year has been verified as the most extreme dry period in the century-long record of discharge 


\section{ACTA \\ AMAZONICA}

THE DROUGHT OF THE CENTURY IN THE AMAZON BASIN:

AN ANALYSIS OF THE REGIONAL VARIATION OF RAINFALL IN SOUTH AMERICA IN 1926. from the western sub-basin of the Amazon. The regional rainfall anomaly for 1926 is negative over this sub-basin and positive further east. The magnitude of the rainfall deficit is broadly consistent with the annual deficit in discharge from that sub-basin (30-40\%). The enhanced rainfall in the Nordeste in this pronounced El Nino year is attributed to an anomalously warm South Atlantic Ocean, consistent with earlier studies. The integrated anomaly for the entire South American chimney in 1926 is modest. Aerosol effects may have been contributed significantly to the magnitude of the negative rainfall anomaly.

\section{ACKNOWLEDGEMENTS}

Discussions on this topic with John Edmond, Robert Meade, Hilgard O'Reilly Sternberg, Fatih Eltahir, Carlos Nobre, Pedro Dias, Teresinha Xavier, Tom Rickenbach, Jeff Richey and Jose Marengo are greatly appreciated. Maria Teresa Martelo, Lelys Bravo, Alicia Moreau, Horacio Torres, Guillermo Obregon, Ignacio Rodriguez-Iturbe, and Colin Price all played important roles in providing access to rainfall data for South America. Robert Meade provided a detailed review of the text. Discussion and collaboration with Daniel Rosenfeld on aerosol effects in Brazil, and the support of the U.S.-Israel Bi-National Science Foundation, are acknowledged. Frederic Changnon found several important references on ENSO-related rainfall observations. Nilton Renno provided early information on the rich archive of meteorological data for South America in Brasilia. Ines Moreira de Araujo and Christina Moyses were also helpful in retrieving archived data at INMET. Rosangela Gin assisted in translation. Marie Dow provided all illustrations. This study was enabled in its early stages by a NASA TRMM grant (NAG5-9637) to participate in the 1999 TRMM LBA field experiment in Rondonia, Brazil. We thank R. Kakar, O. Thiele and R. Adler at NASA for their support. Later support from the U.S. National Science Foundation (ATM 0003346) enabled its completion, and we thank R. Rogers and A. Cooper for their assistance.

st - West Cross-Section for Drought Year 1926

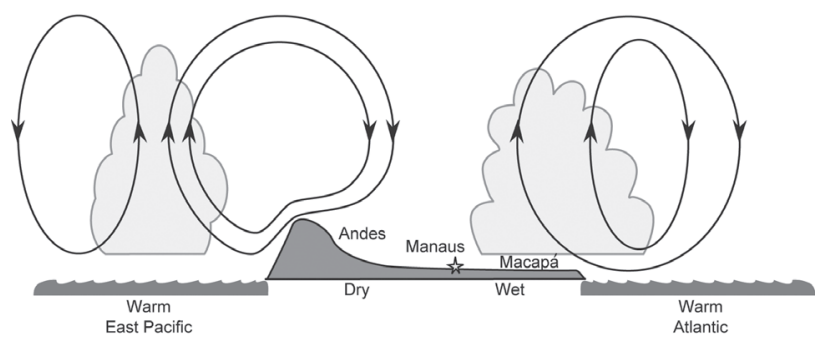

Figure 7 - East-west cross section over tropical South America illustrating likely synoptic scale circulation features associated with the east-west dipole for the rainfall anomaly in the dry year 1926.

\section{LITERATURE CITED}

AAllan, R., Lindesay, J.; Parker, D. 1996. El Nino Southern Oscillation and Climate Variability. CSIRO Publishing, Australia. 405 pp.

Amarasekera, K.N.; Lee, R.F.; Williams, E.R.; Eltahir, E.A.B. 1997. ENSO and the natural variability in the flow of tropical rivers, J. Hydrology, 200: 24-39,

Christian, H.J.; Blakeslee, R.J.; Boccippio, D.J.; Boeck, W.L.; Buechler, D.E.; Driscoll, K.T.; Goodman, S.J.; Hall, J.M.; Koshak, W.J.; Mach, D..M.; Stewart, M.F. 2003. Global frequency and distribution of lightning as observed from space by the Optical Transient Detector, J. Geophys. Res., 108, 4005, doi: 10.1029/2002JD002347.

Dennison, L.R. 1943. Caroni Gold. Hastings House: New York. 274 pp.

Ferreira, R.N.; Rickenbach, T.M.; Herdies, D.L.; Carvalho, L.M.V. 2003. Variability of South American convective cloud systems and tropospheric circulation during January-March 1998 and 1999. Mon. Wea. Rev., 131: 961-973.

Hansen, J.E.; Lebedeff, S. 1987. Global trends of measured surface air temperature, J. Geophys. Res., 92:13345-13372.

Hastenrath, S.; Wu, M. C.; Chu, P.S. 1984. Towards the monitoring and prediction of Northeast Brazil droughts. Quart. J. Roy. Met. Soc., 110: 411-425.

Kent, G.S; Williams, E.R. ; Wang, P.H. ; McCormick, M.P. ; Skeens, K.M. 1995. Surface temperature-related variations in tropical cirrus clouds as measured by SAGE II. J. Climate, 8: 2577-2594,

Kiladis, G.N.; Diaz, H.F. 1989. Global climatic anomalies associated with extremes in the Southern Oscillation. $J$. Clim., 2:1069-1090,

Koch-Grunberg, T. 1917. Vom Roraima zum Orinoco, Vol. 1: Dietrich Reimer, Berlin, 406pp.

Kousky, V.E.; Chu, P.-S. 1978. Fluctuations in annual rainfall for northeast Brazil. J. Met. Soc.: Japan, 56:457-465.

Knoch, K. 1926. Die Starke atmosphärische Trubung im Jahre 1926 in Venezuela, Meteorol. Z., 43: 421pp.

Knoche, W. 1937. Der Einfluss von Vegetationsbranden auf die Witterung. Meteorol. Z., 54: 243-254.

Marengo, J.A. 1995. Variations and change in South American streamflow. Climatic Change, 31: 99-117.

Marengo, J.A. 1992. Interannual variability of surface climate in the Amazon basin. International Journal of Climatology, 12: 853-863.

Markham, C.G. 1973. Apparent periodicities in rainfall at Fortaleza, Ceara, Brazil. J. Appl. Met., 13: 176-179.

Markham, C.G.; McLain, D.R. 1977. Sea surface temperature related to rain in Ceara, north-eastern Brazil. Nature, 265: 320-323.

Meade R.H.; Dunne, T.; Richey, J.E.; Santos, U. de M.; Salati, E. 1985. Storage and remobilization of suspended sediment in the lower Amazon River of Brazil. Science 228: 488-490. 
Meade, R.H.; Rayol, J.M. Conceição, S.C. ; Navidade, J.R.G. 1991. Backwater effects in the Amazon basin of Brazil. Environmental geology and water science, 18 (2): 105-114. (Also published in Portuguese: Efeitos de remanso na bacia do rio Amazonas no Brasil. A Água em Revista, vol. 1, no.1, 21-30, 1993.)

Moody, J.; Meade, R. 1998. Gage Datum at Manaus, Memorandum, United States Geological Survey (Denver Federal Center, Denver, CO), 9 March. 5pp.

Murphy, R.C. 1926. Oceanic and climatic phenomena along the west coast of South America during 1925. Geographical Review 16 (1): 26-54.

Obregon, G.O.; Nobre, C.A. 2002. Variabilidade climática sobre a bacia Amazonica: Processos de multipla escale e não estacionários, LBA meeting, Manaus, Amazonas, Brazil, July.

Orville, R.E.; Henderson, R.W. 1986. The global distribution of midnight lightning: December 1977 to August 1978, Mon. Wea. Rev., 114: 2640-2653.

Riehl, H.; Meitin, J. 1979.Discharge of the Nile River: a barometer of short-period climate variation. Science. 206:1178-1179.

Richey, J.E.; Nobre, C. ; Deser, C. 1989. Amazon river discharge and climate variability: 1903-1985, Science, 246:101-104

Ropelewski, C.F.; Halpert, M.S. 1987. Global and regional scale precipitation patterns associated with the El Nino/Southern Oscillation. Mon. Wea. Rev., 115:1606-1626.

Rosenfeld, D. 1999. TRMM observed first direct evidence of smoke from forest fires inhibiting rainfall, Geophys. Res. Lett., 26: 3105-3108.

Stallard, R.F.; Edmond, J.M. 1981. Geochemistry of the Amazon: 1. Precipitation chemistry and the marine contribution to the dissolved load at the time of peak discharge, J. Geophys. Res., 86: 9844-9858.

Sternberg, H.; O'Reill. 1968., Man and Environmental Change in South America, in Biogeography and Ecology in South America, ed., E.J. Fittkau, J. Illies, H. Klinge, G.H. Schwabe and H. Sioli, Dr. W. Junk N.V. Publishers, The Hague. p.413-445.
Sternberg, H. O'Reilly. 1987. Aggravation of floods in the Amazon as a consequence of deforestation?, Geografiska Annaler, 69A: 201-219.

Whipple, F.J.W. 1929. On the association of the diurnal variation of electric potential gradient in fine weather with the distribution of thunderstorms over the globe, Quart. J. Roy. Met. Soc., 55: 1-17.

Williams, E.R. 1992. The Schumann resonance: A global tropical thermometer. Science. 256:1184-1187.

Williams, E.R.; Rosenfeld, D.; Madden, N.; Gerlach, J.; Gears, N.; Atkinson, L.; Dunnemann, N. ; Frostrom, G.; Antonio, M.; Biazon, B.; Camargo, R.; Franca, H.; Gomes, A.; Lima, M.; Machado, R.; Manhaes, S.; Nachtigall, L.; Piva, H. ; Quintiliano, W. Machado, L. ; Artaxo, P.; Roberts, G. Renno, N.; Blakeslee, R.; Bailey, J. Boccippio, D. Betts, A.; Wolff, D. Roy, B.; Halverson, J.; Rickenbach, T. ; Fuentes, J. ; Avelino, E. 2002. Contrasting convective regimes over the Amazon: Implications for cloud electrification. J. Geophys. Res., LBA Special Issue, 107(D20): 8082,doi:10.1029/2001JD000380.

Xavier, T. 2001 Tempo de Chuva: Estudos Climáticos e de Previsão para o Ceará e Nordeste Setrentrional, Editora ABC, Fortaleza-Ceará-Brasil, 478 pp.

Xie, P.; Rudolf, B.; Schneider, U.; Arkin, P.A. 1996. Gauge-based monthly analysis of global land precipitation from 1971 to 1994.J. Geophys. Res., 101:19023-18034.

RECEBIDO EM 10/07/2003 ACEITO EM 19/05/2005 